\title{
Factors influencing jumantik performance in dengue infection prevention at South Denpasar, Bali
}

\author{
A Santosa ${ }^{1 *}$ and IBA Satwika Ekananda ${ }^{2}$ \\ ${ }^{1}$ Faculty of Medicine and Health Sciences, Universitas Warmadewa, Denpasar, Bali \\ *omangbabe@gmail.com
}

\begin{abstract}
The study purpose was to find out factors influence the performance of Jumantik in Puskesmas II South Denpasar. This is cross sectional study with the total samples of 32 Jumantik in Puskesmas II South Denpasar. The obtained data analyzed by chi square test and logistic regression test. Based on bivariate analysis, there were no significant correlations between characteristic (age, gender, education, tenure, and additional work) and Jumantik's attitudes with the occurrence of DHF indicated by $\mathrm{p}>$ 0.05 . However, there were significant correlations between Jumantik's capability $(\mathrm{p}=0.02)$, Jumantik's motivation $(\mathrm{p}=0.014)$, award given $(\mathrm{p}=0.008)$ and monitoring/evaluation $(\mathrm{p}=0.001)$ with dengue occurrence $(\mathrm{p}<0$. 05). Variables influenced the occurrence of DHF were Jumantik's capability $(\mathrm{p}=0.014)$ and monitoring/ evaluation $(\mathrm{p}=0.011)$. Multivariate analysis result there was significant correlation between the monitoring/ evaluation variables with DHF occurrence, with OR 20.40 which means that if there were no monitoring and evaluation to Jumantik then the risk of DHF occurrence were 20.4 times greater than that in the presence of monitoring/evaluation. The study showed that the most influential factors of DHF occurrence are the ability of Jumantik and monitoring the evaluation of Jumantik.

Keyword : Influencing, Prevention.
\end{abstract}

\section{Introduction}

Dengue Hemorrhagic Fever (DHF) is one of the infectious diseases caused by dengue virus transmitted by Aedes aegypti and Aedes albopictus [1]. The number of dengue cases tends to increase and cause many deaths [2]. Mosquito-breeding sites in humid environment, high rainfall, there is a puddle of water [3]. From 1968 to 2009, the World Health Organization (WHO) noted Indonesia as the country with the highest cases of Dengue Fever in Southeast Asia.1 Extraordinary events in Indonesia occur every year. Some provinces, the largest occurred in 1998 and 2004 with 79,480 people affected and over 800 deaths [2, 4]. This disease continued to develop, until 2009. The province of Bali is an endemic area of dengue with IR in fourth place after DKI Jakarta, West Kalimantan and East Kalimantan [5]. The city of Denpasar accounted for the largest dengue case with an incident rate in Bali with of 143.2 cases per 100,000 population in $2013[5,6]$..

Data from the Denpasar City Health Service shows that the highest DHF cases are in South Denpasar District. Total dengue patients in 2011 were 371 people with one person died [7]. The Denpasar City Health Office made various efforts to reduce the number of dengue fever cases by empowering the larvae monitoring staff (Jumantik) recruited from the community to carry out periodic larvae checks and to mobilize the community to carry out the DHF mosquito breeding eradication. Larva monitoring result was obtained by filling out the periodic monitoring form. A Jumantik should have sufficient knowledge about DHF because 
they must educate the community. Jumantik must also have a positive perception and high motivation in carrying out tasks

The Jumantik activities are budgeted from the Regional Budget (APBD) of the City of Denpasar. In 2015, the number of Jumantik in Denpasar City was 430 people spread across 43 villages in 430 Banjars. Every Jumantik gets an honorarium of IDR 900,000.00 / month. Every Jumantik is expected to visit 25-30 families every working day from 08.00 to 12.00 a.m. Based on data from the Denpasar City Health Office in 2012 the number of Jumantik in South Denpasar District consisted of 105 Jumantik people with 11 Jumantik coordinators spread across four health centers [8]. The existence of Jumantik in Denpasar City has existed since 2007. The Denpasar City Health Service successfully suppressed the incident rate (IR) DHF that reached 132.8 per 100,000 inhabitants in 2012. When compared with the 2006 data when there was no Jumantik, IR from DHF reached 620 per 100,000 populations, but in subsequent years, there was an increase in dengue cases [7]. The city of Denpasar accounted for the largest dengue case with an incident rate of 143.2 per 100,000 populations in 2013[5].

The Puskesmas II Denpasar Selatan area is one of the areas with a high case in South Denpasar. Based on data from South Denpasar Health Center II in the last three years, dengue cases have increased. The number of cases in 2014 was 123 cases, in 2015, there were 140 cases, and the numbers of cases in 2016 were 321 cases with 1 case died. Based on the description above, the author wants to examine the factors that influence the performance of Jumantik on the incidence of DHF in the Regional Health Center II in South Denpasar.

\section{Method}

\subsection{Data Collection}

The study conducted at Puskesmas II Denpasar Selatan from October to December 2017. The design of this study is analytic description research through a cross-sectional approach. No sampling was carried out, total (32) Jumantik were used as respondents. Independent variables (ability, attitude, motivation, incentive and monitoring/evaluation), dependent variables (DHF incidence) and confounding variables (demographic characteristics: age, sex, education, years of service, additional work). Data collected through direct interviews with Jumantik and from secondary data on the incidence of DHF in 2016 at Puskesmas II Denpasar Selatan.

\subsection{Statistical analysis}

Data processed in a categorical form, and then analyzed using the chi square test to determine the relationship of independent variables with dependent variables, after that using the logistic regression test to determine the effect of independent variables on dependent variables.

\section{Results And Discussion}

Table 1. Characteristic of jumantik

\begin{tabular}{lcc}
\hline \multicolumn{1}{c}{ Variable } & Frequency & Percentage (\%) \\
\hline $\begin{array}{c}\text { Age (y.o) } \\
17-30\end{array}$ & 2 & 6.3 \\
\hline
\end{tabular}




\begin{tabular}{lcc}
\hline \multicolumn{1}{c}{ Variable } & Frequency & Percentage (\%) \\
\hline >30 & 30 & 93.8 \\
Gender & & \\
Female & 29 & 93.8 \\
Male & 3 & 9.4 \\
Education & & \\
$\quad$ High school & 29 & 90.6 \\
$\quad$ University & 3 & 9.4 \\
Additional job & & 50 \\
$\quad$ Yes & 16 & \\
\hline
\end{tabular}

The Jumantik capability showed 19 people (59.4\%) who were not capable while 13 people $(40.6 \%)$ were able. Based on the results obtained showed three people $(9.4 \%)$ had a nonsupportive attitude while 29 people $(90.6 \%)$ had a supportive attitude. The motivation study showed 17 people $(53.1 \%)$ lacked motivation while 15 people $(46.9 \%)$ had good motivation. Twenty-two Jumantik $(68.8 \%)$ had no incentive, while 10 people $(31.3 \%)$ had incentive for Jumantik.

Monitoring/evaluation study showed that 17 people (53.1\%) had no monitoring/evaluation while 15 people (46.9\%) had monitoring and evaluation. DHF events showed that $13(40.6 \%)$ Jumantik work areas had no dengue incidence while 19 (59.4\%) Jumantik work areas had dengue incidence.

Table 2. Bivariate analysis

\begin{tabular}{lc}
\hline \multicolumn{1}{c}{ Variable } & p-value \\
\hline Age & 1.00 \\
Gender & 0.728 \\
Education & 0.375 \\
Work duration & 1.00 \\
Additional job & 1.00 \\
Jumantik capability & $\mathbf{0 . 0 0 2}$ \\
Jumantik motivation & $\mathbf{0 . 0 1 4}$ \\
Incentive & $\mathbf{0 . 0 0 8}$ \\
Monitoring/evaluation & $\mathbf{0 . 0 0 1}$ \\
\hline
\end{tabular}

According to table two only Jumantik capability, motivation, award achievement and monitoring/evaluation significantly associate with the occurrence of DHF. Multivariate analysis with logistic regression test is resumed in table 3

Table 3. Multivariate analysis

\begin{tabular}{llrr}
\hline \multicolumn{1}{c}{ Variable } & Adjusted OR & $\mathbf{9 5 \%}$ CI & p-value \\
\hline Jumantik capability & 19.374 & $1.803-208.137$ & 0.014 \\
Monitoring/evaluation & 20.408 & $2.026-247.835$ & 0.011 \\
\hline
\end{tabular}

The results of multivariate analysis with the Forward method have two variables that influence the incidence of DHF, namely the ability $(\mathrm{p}=0.014)$ and monitoring evaluation $(\mathrm{p}=$ 0.011). Variable monitoring/evaluation with a value of OR 20,408 means that if there is no monitoring/evaluation of Jumantik, the risk of dengue incidence is 20.4 times greater than the presence of monitoring and evaluation. Whereas for the Jumantik capability variable has OR 
19,374 which means that if you have low ability, it increases the risk of dengue incidence 19.3 times greater than the high ability

This study examined the relationship between age and incidence of DHF. Based on the results of bivariate analysis, the age variable with a value of $p=1,000$ means that there is no significant relationship between age and the incidence of DHF as indicated by the value $\mathrm{p}>$ 0.05. This is in line with the research conducted by Sali et al. (2013) [6] and Aprinianis et al. (2014) [11] obtained $p>0.05$, that there is no relationship between age and performance of jumantik

Based on the results of bivariate analysis, there was no significant relationship between genders with the incidence of DHF as indicated by the value $\mathrm{p}>0.05$. This finding also support by another study where they did not found any association between age of Jumantik and DHF occurrence [12].

The bivariate analysis show there was no significant relationship between education and the incidence of DHF ( $p>0.05)$. The results of this study are in line with Aprinianis's research (2014) [11] that there is no significant relationship between education level and Jumantik performance in the study site $(\mathrm{p}>0.05)$.

This study found no significant association between working duration and the incidence of DHF as indicated by the value $\mathrm{p}>0.05$. This result is in line with the research of Novi Dwi \& Sugiyanto (2014) [13] that there is no relationship between the working duration and ABJ status ( $p>0.05$ ). This is possible because Jumantik has boredom for working period so that the longer it works; Jumantik considers the task as a habit without balanced with a sense of responsibility.

Based on the results of bivariate analysis, there is no significant relationship between additional work and the incidence of DHF indicated by the p-value $>0.05$. This research is in line with the research of Istiqomah et al (2017) [14] that there is no relationship between work and efforts to prevent DHF ( $\mathrm{p}>0.05$ ).

The results of multivariate analysis showed the capability to influence the incidence of DHF. This study is in line with Sali's (2013) [6] research on the performance of Jumantik in monitoring Aedes aegypti larvae that the influence of this ability is markedly seen from ( $p$ $<0.01$ ). Capability plays an important role in individual performance, because capability is one of the important factors in improving work performance.

The Jumantik motivation showed that there was no influence between motivation and the incidence of DHF in this study. This study is in line with Dwi Putri's research (2016) [16]. There was no influence between the incentive and the incidence of DHF in this study. This research is in line with the research of Desi Ary Sandhi \& Martini (2014) [8] regarding the influence of incentive factors on the performance of larva monitors in carrying out the eradication of mosquito nests, that the incentive had no significant effect ( $p>0.05)$. This is because the incentive they want is not a matter of money but there is an appreciation for the performance they have done while being Jumantik

Multivariate analysis showed that monitoring and evaluation were very influential in the incidence of DHF. This research is in line with Desi Ary Sandhi \& Martini's (2014) research [8]. The results of multivariate analysis show that supervision whose meaning is in line with monitoring and evaluation has an effect on the performance of the Jumantik with a p-value of 0.000 . 


\section{Conclusions}

The ability of Jumantik capability, motivation, award given and monitoring/evaluation influence the occurrence of DHF in South Denpasar. On the other hand there is no effect of internal factor of Jumantik in the DHF occurrence in the study site..

\section{References}

[1] Maria I, Ishak H, Selomo M 2013 Faktor risiko kejadian demam berdarah dengue (DBD) di Kota Makassar Alumni kesehat lingkungan Fakultas Kesehatan Masyarakat UNHAS bagian kesehat lingkungan Makassar (Dengue Hemorrhagic Fever) pp 1-11

[2] Candra A 2010 Demam berdarah dengue: epidemiologi, patogenesis, dan faktor risiko penularan Aspirator 2 pp 110-9

[3] Gama T A and Betty R F 2010 Analisis faktor risiko kejadian demam berdarah dengue di Desa Mojosongo Kabupaten Boyolali Fakultas Ilmu Kesehatan Universitas Muhammadyah Surakarta 5 pp $1-9$

[4] Wati W E 2009 Beberapa faktor yang berhubungan dengan kejadian DBD di Kelurahan Ploso Kecamatan Pacitan tahun 2009 Program Studi Kesehat Masyarakat Fakultas Ilmu Kesehatan Universitas Muhammadyah Surakarta

[5] Subagia K, Agung A, Sawitri S, Wirawan N and Wirawan D N 2013 Lingkungan dalam rumah, mobilitas dan riwayat kontak sebagai determinan kejadian demam berdarah dengue di Denpasar tahun 2012 Public Heal. Prev. Med. Arch. 2013 1(1) pp 1-7

[6] Sali W 2013 Faktor yang mempengaruhi kinerja jumantik dalam memantau jentik aedes aegypti di Kecamatan Denpasar Selatan Kota Denpasar J. Skala Husada 10 pp 136-58

[7] Hadi M C, Rusminingsih N K and Marwati N M 2015 Peran jumantik dalam menurunkan insidens rate DBD di Denpasar J. Skala Husada pp 89-95

[8] Desi Ary Sandhi N P and Martini N K 2014 Pengaruh faktor motivasi terhadap kinerja juru pemantau jentik dalam pelaksanaan pemberantasan sarang nyamuk di Kecamatan Denpasar Selatan tahun 2013 Community Health (Bristol) II(1) pp 1-11

[9] Dodi A A 2014 Implementasi peraturan daerah Provinsi Daerah Khusus Ibukota Jakarta nomor 6 tahun 2007 (pengaruh pengawasan dan disiplin terhadap kinerja juru pemantau jentik di Kelurahan Tambora Kecamatan Tambora kota administrasi Jakarta Barat) Program Pascasarjana Univ Esa Unggul Jakarta

[10] Dinas Kesehatan Kota Denpasar 2015 Profil kesehatan Kota Denpasar tahun 2011

[11] Aprinianis R I B 2014 Faktor-faktor yang berhubungan dengan kinerja jumantik di wilayah kerja Puskesmas Jurangmanggu dan Puskesmas Pondok Aren Kota Tangerang Selatan tahun 2012. Progr. Pasca Sarj. Ilmu Kesehat. Masy. pp 1-67

[12] Widaningsih 2016 Pengaruh karakteristik terhadap kinerja perawat pelaksana di ruang perawatan intensif rumah sakit kelas A dan B di Indonesia Indones. J. Nurs. Heal. Sci. 1 pp 7583

[13] Novi Dwi A and Sugiyanto Z 2014 Hubungan antara karakteristik juru pemantau jentik (Jumantik) terhadap status angka bebas jentik (ABJ) di Kelurahan Wonotingal wilayah kerja Puskesmas Kagok Tahun 2014 Fak. Kesehat. Univ. Dian Nuswantoro Semarang pp 1-11

[14] Istiqomah B M S and Husodo B T 2017 Faktor-faktor yang berhubungan dengan upaya pencegahan demam berdarah dengue (DBD) pada ibu rumah tangga di Kelurahan Kramas Kota Semarang J. Kesehat. Masy. 5 pp 203-12

[15] Muliawati E 2016 Hubungan pendidikan dan pelatihan jumantik dengan keberhasilan program PSN di Kelurahan Tanah Kalikedinding Kota Surabaya J Keperawatan Muhammadiyah 1(2) pp $1-16$ 
[16]Dwi Putri Y 2016 Upaya pencegahan DBD oleh juru pemantau jentik (Jumantik) dan hubungannya dengan angka bebas jentik (ABJ) di wilayah kerja Puskesmas Rawa Buntu Kota Tangerang Selatan tahun 2016 Universitas Islam Negeri Syarif Hidayahtullah Jakarta pp 1-136 